Kingsley Ekene Amaechi ${ }^{1}$

$316.334 .55(680)$

University of Venda,

616.98:578.834]:352.9

School of Human and Social Sciences,

Original scientific paper

Centre For African Studies (Sociology Section)

Submitted 03/03/2021

Ishmael Obaeko Iwara ${ }^{2}$

Accepted 04/05/2021

University of Venda, School of Agriculture,

Institute for Rural Development

Faith Musvipwa

University of Venda,

School of Human and Social Sciences,

Centre For African Studies (Sociology Section)

Raymond Raselekaone

University of Venda,

School of Human and Social Sciences,

Institute for Gender and Youth Studies,

Thohoyandou (South Africa)

\title{
APPRAISING THE LOCAL VILLAGE LEADERS“ RESPONSE TO THE CHALLENGES FACED BY RURAL HOUSEHOLDS DURING THE CORONA VIRUS 2019 NATIONAL LOCK-DOWN IN SOUTH AFRICA
}

Abstract: This study investigates Tswinga village local leaders' efforts in responding to COVID-19 pandemic challenges grappling its households. It draws from ideas in Afrocentrism to evaluate local community leaders' response to the pandemic during the first 65 days of the South African COVID-19 lockdown. Data were collected through semi-structured interviews of both local leaders of the village and the local Municipality's COVID-19 response team. The study found that no significant progress in the fight against the COVID-19 would have been made if the national strategy to combat the virus had not been adapted to the local situation by local leadership. Hence, the study recommends a comprehensive multi-stakeholder involvement and a bottom-up approach when developing strategies to curb the pandemic to ensure that the strategy responds to the varying dynamics prevailing in different regions of the country.

Keywords: Afrocentricity, COVID-19 pandemic, national lockdown, socio-economic challenges, rural households

\footnotetext{
1 kingsley101amaechi@gmail.com

2 Ishmael.iwara@gmail.com
} 
Kingsley E. Amaechi, Ishmael O. Iwara, Faith Musvipwa, Raymond Raselekaone, Appraising...

\section{Introduction}

The onset of the Corona virus (COVID-19) pandemic in late 2019 triggered unprecedented response from countries around the world (Kumari \& Toshniwal, 2020; Iwara; Amaechi, Musvipa \& Raselekaone, 2020). In most cases, such responses have included an implementation of very stringent shut-down of economic and social activities with an aim to reduce the spread of the virus. These entailed measures such as travel restrictions, prohibition of public and social gatherings (including religious services), closure of businesses, and many others (Iwara et al., 2020). Reports from the World Health Organisation shows that there is rarely a country around the world that has not adopted one form or another of such restrictions in response to the pandemic, and this is ideal.

In South Africa, the response has largely followed this strict social and economic lockdown approach in line with the WHO. The government response, inter alia, has involved five-stage alert levels of economic and social restrictions and lockdowns (with the fifth stage being the highest level for restrictions). The fifth and fourth level, which lasted for 35 days (from the 26th March until 30th April) and 30 days (from 1st May to 31st May) respectively, has entailed closure of borders, prohibition of interprovincial travel, except for, to return to work with proof of employment and for exceptional events such as funerals (with approval), and prohibitions of social and economic activities, except for essential workers (South African Government, 2020). However, with improvements in the infections and recovery rates, as well as the serious negative implications the pandemic had on the economy(Arndt et al., 2020), the country subsequently moved to level three, which entail less social and economic restrictions (Republic of South Africa, 2020). The country would also ease the lockdown to alert level two, until December 2020, when a new variant that seemed to spread faster was discovered in the country. The country has now returned to the adjusted alert level 3 (South African Government, 2020).

Evidently, the control measures put in place by the South African government have played a significant role in managing and reducing the spread of the virus. However, they have exposed the country's households to serious socio-economic challenges (Arndt et al., 2020), especially those in the rural communities (Iwara et al., 2020). In light of the fact that many households in such areas of South Africa sorely rely on small informal businesses and subsistent farming (Fransman \& Yu, 2019; Mukumbang et al., 2020), it became extremely difficult for them to be involved in their activities amidst the lockdown (Iwara et al., 2020).

Interestingly, stringent control measures are not the only reason people in rural households find navigating life during the pandemic challenging; actions of local leaders also have a role to play (Dirani et al., 2020; Ghosh, 2020; Haffajee \& Mello, 2020). The way the local leaders in different communities interpret the national lockdowns has impacted how individuals living within different local communities experience and perceive the pandemic. Even though living during the pandemic can be generally devastating, the economic and the social impact of the pandemic have been reduced by the combined input of members of the community and measures introduced by local leaders, in response to the specific challenges faced by individuals within the community (Dirani et al., 2020; Ghosh, 2020; Haffajee \& Mello, 2020). Attending to the specific needs and challenges within the communities influences how the pandemic is interpreted and felt within communities 
(Semi-annual Report of the Latin America and Caribbean Region, 2020). Yet, such important analysis is hardly explored in previous South African COVID-19 literature. This study is an attempt to fill this gap.

The analysis of the role of local leaders' response on the interpretations and experiences of the pandemic by households in rural areas are drawn from the documentation and study of intervention strategies used by the Tswinga leaders to address the socio-economic challenges during the fifth and fourth alert levels (the first 65days of the South African nation COVID-19 lockdown). Local leaders from this village were according to the local Municipality's report on COVID-19 (Thulamela COVID-19 Report, 2020) among the first group of local leaders to show exemplary leadership in finding strategies that helped address some of the socio-economic challenges that confronted rural households, as documented by Iwara et al., 2020. The study is thus guided by the following questions: (a) What are the strategies used by the local leaders in the village to address the challenges? (b) What is the rationale behind these strategies? and (c) In what ways have the strategies helped address the unique challenges the rural households faced during the 65 days?

Our discussion is premised on the Afrocentricity literature; particularly on Molefi Kete Asante (2010), whose philosophical and conceptual framework of Afrocentricity embodies a constructural adjustment to African orientation, centeredness and faith in the African values as the provider of solutions to local issues within the African continent. The argument is that solutions to local issues in Africa, are better drawn from the African local community, (from the people) from which the problem exists. Given the commonality of cultures and shared value systems actors within the community have with each other, they themselves are believed to be in better position to understand and proffer solutions to the communities' problems (Asante, 2010). They are also better positioned to understand how specific measures (even if adopted from other settings) could be appropriately applied to provide the correct solution to the challenges within their communities (Asante, 2010).

This is not to be misunderstood to mean that solutions based on euro-centric epistemological and philosophical outlook are fundamentally inadequate. Rather, our point is that solutions to local problems should be generated from the local people. In other words, they should be locally based and adopted. Even if such problems are foreign imposed, they still require local interpretation. Admittedly, the COVID-19 pandemic is global problem, its impact on the different African communities are peculiarly unique to those African communities. Hence, unique community solutions drawn within those communities may be the most appropriate way to address some of the challenges the pandemic has brought about in African communities.

The study is organized in such a manner that this introduction provides the background and a quick review of the extant literature on the impact of the South African national lockdown on rural households. This is followed by a discussion of methodological issues underpinning the study. From there, the data comprising of the key strategies used by the local community leaders to address the socio-economic challenges of the national lockdown, and its implications are presented. The paper concludes with salient policy recommendations for South Africa, especially as it relates to rural communities. 
Kingsley E. Amaechi, Ishmael O. Iwara, Faith Musvipwa, Raymond Raselekaone, Appraising...

\section{Method and data}

In documenting and appraising the Tswinga Village Leaders' response, the study had adopted qualitative exploratory design, within which it was possible to capture the different activities of the local representatives of the selected village. Three sets of participants were purposefully selected for the collection of data. These are two members of the Thulamela Municipality's COVID-19 Committee, two ward councillors, representing the Tswinga village within the municipality, and two members of Tswinga village traditional council. Using focus group and semi-structured in-depth interviews, detailed information about the activities and efforts of the local representatives of the village was carefully collected from the participants.

A thematic analytical technique was used to harness and analyse the data. This technique was ideal given that it enabled a careful distillation of the local government's responses (as themes) to the identified socio-economic challenges which the rural households grappled with amidst the COVID-19 national lockdown. Thematic analysis method also aided in evaluating whether such efforts substantially addressed the challenges that households at Tswinga village had to grapple with.

The qualitative data were transcribed and categorised. Quotes related to the government responses to the different socio-economic issues were carefully distilled and coded, along the different sets of participants that were used in the study. Acronyms such as TMCT for the Thulamela Municipality COVID-19 team, WC for Ward Councillors, and TTC for representatives from the Tswinga Traditional Council were used to code views of the participants in a word document. These codes are consequently presented in Table 1 for a clear understanding of the result.

\section{Intervention strategies used by the local community leaders to address the socio-economic challenges of rural households at Tswinga}

From the participants' narratives in the interview data, seven themes were deduced as intervention strategies employed by the local community leaders to address the several challenges that people living in rural households at Tswinga village faced during the first 35 days of national lock-down. These include: 1) 'provision water', 2) 'provision of food', 3) 'facilitation of access to health care, 4) 'provision of additional income for sustenance, 5) 'provision of information and psychological support to deal with COVID-19 anxiety', 6) 'social support to domestic violence victims' and 7) rapid response and intervention on criminal activities. These themes are presented in Table 1 and discussed in the section below:

\subsection{Provision of Water}

As indicated in Table 1 the initial responsibility of providing water for the Tswinga community was reserved for the local Thulamela Municipality. According to the representatives from the Municipality's COVID-19 team, the Municipality drew its mandate from the country' declaration of the pandemic as the "National State of Disaster." By declaring the "national state of Disaster", Municipalities in different parts of the country were empowered 
to make additional provision for water, food and other essentials for the people (based on the National Disaster Management Act). The declaration also empowered them to assess newly designated funds meant for COVID-19 during those periods. Hence, the Thulamela Municipality, through it specially formed COVID-19 committee, could mobilise resources to distribute water to the different villages within the Municipality.

In distributing the water, drums and tankers were used by the local municipality. However, the water distribution hardly reached many households at the village. The Municipality's efforts were hardly good enough to address the water crisis the rural households in the village faced during the 35 days national lockdown. This is how one of the ward councillors in the village puts it:

"Even though the municipality was supplying people with water through tankers, not all the places in the village were covered. We were still experiencing water crisis in many parts of the village. This is mostly because only few households got access to the Municipality's water. In fact, very few villagers benefitted from this initiative. And even those privileged few who benefited, did not get the water supply constantly either... We can confidently say that only a few areas in our village were covered, while a clear majority were left to struggle on their own, it was sad..." (WC1)

A more detailed explanation was provided by the second ward councillor, who himself claimed to have more information on the workings of the Municipality's COVID-19 committee. The participant did recognise that the villagers indeed suffered what he called "multiplied lack of access to water" during the first 35 days national lockdown period. However, he was reluctant to blame the Municipality for that. In his view, the water crisis in the village had been there before COVID-19. It was not something the Municipality would have solved within the 35-day lockdown period. This is how he explained it:

"Maybe it may be too harsh to blame the Municipality for the lack of adequate water supply in the village, as some of the water crisis in our village had been there before COVID-19. From our experience, I can admit that very few areas have good water supply from the water supply station, because the taps were and still not working. So, without boreholes, one may have to search for a stream to get water.... This has always been a big challenge for our people. So, it only worsened during lock-down for COVID-19 pandemic, as people are forced to stay home. The Municipality couldn't have solved the community's water problem within such a small period of time." (WC1)

The participant would also go on to argue that some of the households may have also been disproportionately been excluded due to the Municipality's budgetary constraints. Even though the need to provide services such as water supply during the pandemic in the first place may had been based on the South African government's activation of the Disaster Management Act, the amount of funds secured for such services were still limited, he argued. The committee still needed to balance the delivery of water with other services within the period. Such balancing, in his view, actually made it possible for the municipality to avoid delivering the much-needed water to the households that needed it most during the pandemic.

Essentially, the Municipality's water distribution effort did not go far enough in addressing the water crisis in the village, hence the local representatives had to step-in to 
assist the villagers. In collaboration with the traditional council's office, they were able to provide addition supply of water. Given the fact they have access to the information ${ }^{3}$ of the village inhabitants, they could target the most vulnerable and needy villagers. They provided additional water to the elderly, the sick, and the pregnant and nursing mothers in the villages, irrespective of the physical location of their houses. The supply of water here were not limited to ordinary water for taking care of all domestic chores, it also included specially packaged drinking water, which was also considered as very important during this time. Hear one of the representatives from the Tswinga traditional Council explain what they did, and why it was important during that period:

We supplied water to the villagers with our hearts. We delivered water to almost all the needy households in this village. We tried to see that no single needy home was left untouched. ...We couldn't just rely on the efforts of the Municipality. Knowing what our people go through because of water, we felt that it is our duty to put up additional effort throughout this period. We couldn't abandon them this time. In fact, we prioritised them, making sure that they had water to care of their domestic needs. This may not have solved the water crisis we have in this village, but I am sure it had a huge impact in reducing our people's suffering during that period." (TTC1)

\subsection{Provision of Food}

Like in the case of water supply, the initial efforts for providing food were also reserved for the Municipality. First, the Municipality made accelerated effort to provide local spaza shops and wholesalers with a permit to operate during the lockdown. This was done through the Thulamela Municipality COVID-19 Team. Despite the stringent rules against people's free movement, the team also provided people mobility permits that allowed them to go out to buy groceries and perform other essential duties for themselves and members of their households. The rationale for this was twofold: 1) to ensure that the few local businesses within the local communities are kept alive, so that the owners continue to sustain their families, and 2) to make sure that the local population within the villages where such spaza shops operate could also continue to have easy access to groceries during that period. Hear a member of the Thulamela COVID-19 summarise it:

"Giving licenses for local spaza shops to operate was done so that the local businesses could buy their stock since they were granted temporary permission to ensure that community people have access to food and other essential items. This is a good way to mitigate hunger in our localities." (TMCT1)

Considering the strict application of the lockdown rules, especially in terms of restrictions of movement, these measures were very important. It made it possible for "people to have access to easier access to food during those 35 days" (TMCT2). By giving the trading permits to the local spaza shops, the local people who had money could get access to food without necessarily going to the cities.

3 This is information was drawn from the local base developed for distribution of local relieve materials in the village in the past. 
Another important initiative the Municipality had about food provision was to provide food parcels to the people. Unfortunately, they could not do this at the first 35 days due to budgetary constraints. According to the participants, the Municipality could only provide food parcels during alert Level $4^{4}$, as more funds became available (TMCT1). However, the idea of providing food parcel was not neglected. It was taken up by the local representatives, especially the traditional council. The Tswinga traditional leadership played an important role here. Through this office, the members of the council could gain the trust to distribute food to the needy within the village. The traditional ruler's endorsement made it easier for people to accept food that was being distributed to them during the lockdown:

Ah...the traditional ruler's endorsement is very important. You must understand that our people don't just take food from anybody. Often when you give them food, they want to be sure that the gift is genuine. That there are no ulterior motives underneath. So, the food coming from the traditional ruler's office helped to address that fear." (TTC1)

Through the chief's endorsement, the traditional council was also able to partner with various stakeholders to provide donations for food and other relief materials to the needy within the community. With this, they could complement the Municipality's effort; bridging the gap between some of the rural households that were desperately in need of the food parcels, and others who could afford to buy food for themselves from the local spaza shops. And given the traditional council's good knowledge of the community, the distribution of food went very smoothly. This is how a representative from the traditional council explained what they did and how their good knowledge of the village helped in the smooth distribution of the food:

"Most of our food parcels came through private stakeholders. The stakeholders who donated the food parcels would bring those parcels here at the chief's office and people would come to collect, as per groups. The distribution was done at the council and block levels. The block committees would identify needy families in the community since they are the ones working directly with the local people in various blocks. They also used the list from the database to identify those who qualify for the food parcels. Remember, this list was created way before COVID-19 because we already had needy people in the community. Through this method, the distribution of food went so smooth. I can say there were very few, if not zero complaints. Can you imagine? (TTC1)"

\subsection{Facilitation of Access to Health Care}

The activities of the local leaders at Tswinga were also very useful when it came to issues related to healthcare. The participants confirmed that the local leaders liaised with the law enforcement (SAPS) to ensure that there were no restrictions on movement of

4 During this period, the Thulamela Municipality managed to distribute food parcels to few needy and unemployed people within the Municipality, based on the Municipality's database. They liaised with the Department of Social Development (TMCT 2). However, the effort of the Municipality during this period was hardly enough. Hence, it was also complemented by the traditional council and other local representatives within the villages. 
Kingsley E. Amaechi, Ishmael O. Iwara, Faith Musvipwa, Raymond Raselekaone, Appraising...

people, particularly for those in cases of need of medical attention within the village. Here the representative from the traditional council explains it:

"We dealt with the issues of health challenges pretty well in our village. We knew how important health is. You can't play with those kinds of things here, especially when we are aware that people have chronic diseases such as HIV and AIDS. I am sure such people did get their medications. Although these things are very sensitive, we made sure that they did, and constantly....Our community members were getting their medications from the local clinic, especially those with chronic diseases." (TTC 1)

One of the ward councillors also expressed a similar opinion:

"The clinic was made to remain open throughout the period of the lockdown, especially to cater for people with different chronic diseases. ... We are also lucky because in our community it is located in a place where all Members of the community can access it anytime. People were able to go and collect their medication in time and there were no mobility restrictions where health issues were involved." (WC1)

All these views were in fact corroborated by the head of the Thulamela COVID-19 team. The Team leader was also very swift to explain that his office had even gone an extra mile in ensuring that people had access to health care services. According to him, they issued movement permits to people to visit hospitals and clinics any time they wanted.

This is not to be misunderstood as violation of the South African national COVID regulations. In granting people permits to travel to access to the health care facilities, both the Municipality's COVID-19 team and the traditional council had also tried to encourage people to comply with the national COVID-19 regulations, which included proper sanitation, constant washing of hands, and the use of face masks. In fact, face masks were constantly distributed to the people free of charge from the chief's office.

"There were people who donated face masks. Someone donated approximately 300 of them. These masks were then distributed to the people throughout this period from the traditional ruler's office. They are given to them before they go to collect their social grants so as not to be vulnerable to COVID-19 (TTC1).

\subsection{Provision of additional income for subsistence}

In analysing the participants' statements, there is shared belief that the government had played an important role in addressing challenges related to limited resources, which ensued because of economic shutdowns and retrenchments during the national lockdown. The participants acknowledged and appreciated government's efforts in increasing the existing social grants and adding another R350.00 COVID-19 grant for unemployed people within the country. The local leaders' efforts in this regard therefore was more of complementary one; building on the government funds, as well as making sure that people who are qualified for the government grants understood how, where and when to apply for the funds. Below are a few statements that confirm this view discussed above:

"The issue of lack of income due to retrenchments and lockdown has been addressed by government through the Social Relief Grant (SRD). Unemployed South Africans and 
those who lose their jobs/business were paid R350 monthly for subsistent through the South African Social Security Agency (SASSA). Child support grants were also increased so that parents are now able to meet up with their household demands. Our role here was to help the people in making sure that those who qualified for the grants knew the right place to apply, when to apply and how to apply, to enable them get their money." (WC2)

"Following the reception of the government funds, we also created what we called food bank, which has been useful for addressing the challenges related to lack of income. This food bank is where people from different sectors and communities brought their food donations for the needy people around Vhembe. We have also revisited the municipal Integrated Development Plan (IDP) and redirected the focus from the projects, which are not basic and prioritized those which are critical and needed urgent attention like COVID-19." (TMCT1)

"In terms of the resources, we are very lucky in this village because we have Eco-park Project, which is funded by Mphaphuli Development Trust and the Tswinga Royal Council. This project employed 157 villagers. We made sure that the employees received their full salaries throughout the pandemic even though they had not gone to work since the beginning of the lockdown. In a way, we did not directly give these people money, we only facilitated through our influence that they continue to receive the needed funds for their subsistence throughout this period." (TTC1)

These efforts, especially the additional assistance of helping people apply for their grants were arguably very useful. It guaranteed that the villagers, especially those who may not know how to read and write have access to the grants being offered by the government during the period. Getting these kinds of support made living less challenging for most people during the lockdown.

\subsection{Provision of information and psychological support to deal with COVID-19 Anxiety}

Drawing from their many years of experience with working with the villagers, the local community leadership understood quite early that of the biggest challenge people in their community would have could be lack of knowledge and requisite information about COVID-19. Many did not understand the nature of the virus, how it spread, contracted or how it affects the immune system. Such lack of knowledge could cause a lot of anxiety and restlessness in the village (Iwara et al., 2020). It could also lead to frustration and depression, as people may not actually know what to do. In this regard, a high level of awareness and sensitization was deemed necessary. Below is how one of the ward councillors explained what they did.

"We used the media to disseminate the information on COVID-19. We also used our local newspaper to disseminate the information on COVID-19. Although during Level 5 of the lockdown, we were not allowed to get in contact with people, so, the ministers and mayors briefed the public through the television and radio news." (WC1)

Other than the traditional media, the local ward councillor further explained how they used the social media to spread the message about COVID-19. In collaboration with the traditional council, local community leaders created a Facebook page for the village 
Kingsley E. Amaechi, Ishmael O. Iwara, Faith Musvipwa, Raymond Raselekaone, Appraising...

where information about the Coronavirus was constantly disseminated. This enabled proper provision of information for many members of the village. This view is captured as follows by one of the local community leader:

“...through our Facebook page, our councillors were able to share important information with the community members. This information includes the effect of the deadly virus, SASSA application procedures and payments, child grant, old age and disability grant. This also helps us to get direct information from the community members." (WC1)

However, knowing that clear majority of the villagers have no access to digital devices for Facebook, other resources were also harnessed to disseminate information. One of them was the use of a town-crier who made public announcements in the streets of the village.

"We used a public communication system staged in a car to drive around the community to pass out information to the people whenever a need arises. Some non-profit organizations, in conjunction with Departments of Social Development and Health also made door to door visits for sensitization and testing for the virus." (TTC1)

These services were also complemented by the Thulamela Municipality COVID-19 team. The COVID-19 team discussed how they partnered with the local municipality's internal department of Environmental Health and Waste Management, as well as other bodies. These stakeholders helped to develop health education documents that were used for the dissemination of information about COVID-19 around rural communities within the Municipality.

„We collaborated with the workers' unions within the municipality and formulated groups from all our municipal regions, and then delegated those people to disseminate information to their various communities..." (TMCT1)

The local community leaders argued that these different forms of dissemination of information on COVID-19 helped to provide the much-needed information about the pandemic. This calmed people's nerves and addressed their fears about COVID throughout this period.

\subsection{Social support to victims of domestic violence}

The local community leaders were also very useful in providing support to victims of domestic violence throughout this period. According to the participants, such support came mostly in the form of counselling and reporting of the cases to the local South African Police Service (SAPS). One of the local community leaders stated the following in relation to this issue:

"We have many cases relating to domestic violence, since the beginning of lockdown. But we don't really handle such issues, rather what we did was to counsel such victims and refer them to the police. We also follow up with the victims after that. We are always alert and in touch with the police to make sure that those victims get justice." (WC2)

"The issue of domestic violence is something we have been passionate about. Before the lockdown, we used to have visitors from Thohoyandou Victim Empowerment Programme 
(TVEP) to educate the community on issues around domestic violence and crime in general. We have continued with that work during the lockdown." (TTC1)

4.7 Rapid response and intervention on criminal activities around the village

Like the case of domestic violence, issues about crime are not necessarily prerogatives of the local representatives. However, the local community leaders did become involved because of the additional strain such situations presented to the villager during this period. Both the representatives from the traditional council and the ward councillors made it a point of duty throughout this period that they hastened report of case of criminality to the local South African SAPS. This in their view had helped the villagers deal with the challenges that emanated from the lockdown. This is how one of the ward councillors put it:

"Throughout the first days of lockdown, there was a hastened collaboration between us and the local police. We now work almost as police officers. We quickly reported every case of criminality during that period so as to ensure that we lessen the burden of the lockdown on our people." (WC2)

This view is also consistent with the opinion of one of the local community leaders. He said the following with regard to the issue expressed above:

"...even though we didn't handle cases, as they were not our job, we handed all criminal cases over to the police. We worked with them to protect our community from criminal activities throughout this period, and the government has been supportive." (TTC1)

The same local community leader further added:

"In fact, to mitigate robbery, we try to stay vigilant and report every suspicious movement to the police. The police have been patrolling periodically in all areas of the community. They are doing a great job." (TTC1)

The Head of the Thulamela Municipality COVID-19 Team also had a similar opinion of what the Municipality's approach has been during that period, drawing from the Disaster Management Act:

"When there is a pandemic or special assignment in disaster management, there is something called Joint Operation Committee (JOC). This is a structure consisting of different departments to get the common approach of dealing with the issues of crime, health and so forth, to work together with the South Africa local police." (TMCT1)

\section{A Local response to a global pandemic?}

The actions of Tswinga local community leaders' during the first 35 days of the South African national lockdown is arguably a very good example of a local response to a global pandemic. It is a typical example of how local actors could provide local solutions, to local problems with relatively global implications. The seven identified strategies (represented by the themes) address some of the numerous socio-economic challenges identified earlier by previous studies (Iwara et al., 2020) as pressing for the rural households within the 
Vhembe district during the South African COVID-19 national lock-down. The strategies were derived from the intrinsic beliefs and values system, which people at Tswinga village attach to the challenges that arose from the COVID-19 national lockdown. Even though the mandate was at national level through the National Disaster Management Act, the application of the tenets of the document was interpreted locally. This local interpretation maximised its usefulness in providing the correct solution to the challenges people faced in the village Since the community leaders had a good understanding of their people, their cultures and value systems, they were able to generate specific strategies that complemented those of the national government, in addressing specific challenges which the households faced during the first 35 days of the lockdown.

Apparently, the social economic challenges (such as lack of basic information about the virus itself, lack of basic amenities such as roads, food, water, health facilities and other welfare services) which the households at Tswinga village faced are not significantly different from those faced by communities in similar rural communities, during the COVID-19 pandemic (Arndt et al., 2020; Drummond \& Snowball, 2019; Emenike et al., 2017; Fransman \& Yu, 2019; Iwara et al., 2020; World Bank, 2020, Gabriel \& Robinson, 2020). However, because the interpretations of the challenges have been local, community-oriented and intrinsically drawn from the community's systems of beliefs, different strategies introduced by the local leaders have followed a unique different path. For example, the additional identification of the most needy and elderly people in the food and water distribution, using the already existing village data base; the facilitation of access to health care; the rapid and hastened reporting and follow of criminal activities, the provision of emotional support and assistance to domestic violence victims; the dissemination of information about the virus, using Facebook, distribution of pamphlets and locally thought town-crier systems; and finally, the provision of assistance to less educated people in the village, on how to apply for the government's additional grants - these are all minor, but unique strategies that are probably not implemented in other communities. These unique strategies had specifically targeted the unique challenges (such as shortage of food and water; the increased domestic violence and other criminal activities; chronic health disease crises, the lack of information about COVID-19 and the corresponding anxiety it generated; and the relative lack of education among the elderly population of the village), which people at the village faced during the first 35 days. Understanding their community well, the local leaders at Tswinga were able to draw out strategies that complemented both the municipality's and national government's effort in addressing some of the challenges the rural households faced in the village. Such response to the challenges obviously makes navigating the challenges during the pandemic a bit easier for the people.

The idea of helping people who struggled with applying for the government grants and the government additional funds during this time needs to be particularly singled out. Even though the government has put up such social relief measures (R500 increase in the social grant and a R350 welfare grant for unemployed people in the country (COVID-19 Corona Virus South African Resource Portal, 2020), there were designated applications forms to be completed to receive such grants. Studies (Delany \& Jehoma, 2016; Zembe-Mkabile et al., 2015; Wright et al., 2015) show that in most cases people in rural areas lack the skills to fill such forms, and hence often find it difficult to access such government assistance 
meant for them. In such cases, the state putting place such alleviation funds may mean nothing, since the people are not able to access them. Thus, the provision of assistance with the application for the grants was a well thought and useful action that helped many households who could have struggled with filling in such application forms, or those who may not have known where to apply for the grants. This is a typical example of the local leaders understanding of the needs of their community and localising or interpreting the mandate from the National Disaster Management Act to address the specific challenges within their community. This is different from what seems to be the case in many other rural communities in many less-developed societies (Ghosh, 2020; Wilkinson, 2020), where local leaders often favour a complete "copy and paste" approach, drawn from their national government's directives. Even though such national approaches may have merit, their interpretation and application to the communities should be 'local', in such a way that they address the unique challenges people faced in the rural communities. It is through such local interpretations and initiatives, as Alex de Waal and Paul Richards (2020) argue, that more appropriate solutions are provided. A unified national approach is meaningless unless harnessed through local interpretations.

What seems to be the most important lesson here is that local interpretations and solutions should be the basis of response to local challenges even in the era of global pandemics. Infectious disease outbreaks unfold differently in different communities and in accordance with social conditions that only local people and their leaders can know. The basic transmission mechanisms of the virus may be the same everywhere; however, the speed and pattern of spread varies from place to place (Gupta, Nguyen, Rojas, Raman, Lee, Bento, \& Wing, 2020). A densely populated urban or semi-urban settlement will have a different trajectory to a local village such as Tswinga. Therefore, solutions to the challenges in each community should be localized and contextualised (Asante, 2010).

There are no good reasons to disregard the benefits of Tswinga leaders' local approach in addressing the socio-economic challenges during the first 35 days of the South African COVID-19 shutdown. The way the challenges were addressed is a typical example of local leaders' proper understanding of local challenges, and adoption of corresponding appropriate response for the problems. They understood the unique challenges that local people within the village faced. Among other things, the village was dominated by low-income and subsistent households, who depended on day-to-day economic and social activities within the nearby semi-urban communities to survive. They hardly have extra savings reserved for the rainy days. For such people, a few days' lockdown is extremely difficult to survive because of their unique socio-economic conditions. Even though such a response may not adequately solve all the socio-economic challenges that the local households have, it recognises the importance of localising solutions to such challenges. In other words, it is necessary to engage the local leaders and their people in developing appropriate solution mechanisms for local challenges, even when such challenges have global ramifications. 
Kingsley E. Amaechi, Ishmael O. Iwara, Faith Musvipwa, Raymond Raselekaone, Appraising...

\section{Recommendations}

Given the significance of Tswinga village approach, we recommend a contextualization and localisation of strategies used for addressing the COVID-19 challenges in different communities. Such bottom-up approach is extremely crucial for dealing with issues with varying contextual ramifications. It helps to ensure that any response to the unfolding disaster is informed by inputs directly made by those who are directly affected by the unfolding situation. It also ensures that the measures adopted nationally are developed and informed by the circumstances in which local people find themselves. It basically serves as a way to lift up the power of local and contextualised knowledge when dealing with crisis situations in rural communities.

We also recommend a more context-based social mapping of the provinces and districts to ensure that measures developed to curb the prevalent pandemic are relevant and applicable to local communities. This is necessary because the different provinces and districts have their own dynamics that may require localised strategies to ensure that the measures developed to curb the pandemic are effective, and that they do not create more challenges for the local communities. 
Кинсли Екене Амаечи ${ }^{1}$

Универзитет у Венди,

Факултет за друштвено-хуманистичке науке,

Центар за афричке студије (Социолошка секција)

Ишмаел Обаеко Ивара ${ }^{2}$

Универзитет у Венди,

Пољопривредни факултет, Институт за рурални развој

Фаит Мусвипва

Универзитет у Венди,

Факултет за друштвено-хуманистичке науке,

Центар за афричке студије (Социолошка секција)

Рејмонд Раселекоане

Универзитет у Венди,

Факултет за друштвено-хуманистичке науке,

Департман за омладину и родна питања

Тохојанду (Јужноафричка Република)

\title{
ПРОЦЕНА РЕАКЦИЈА ЛОКАЛНИХ СЕОСКИХ ВОЂА НА ИЗАЗОВЕ СА КОЈИМА СУ СЕ СУОЧИЛА ДОМАЋИНСТВА ТОКОМ ЗАКЉУЧАВАҢА УСЛЕД КОРОНАВИРУСА 2019. ГОДИНЕ У ЈУЖНОАФРИЧКОЈ РЕПУБЛИЦИ
}

\author{
(Превод In Extenso)
}

Сажетак: Ова студија истражује напоре локалних вођа села Тсвинга да одговоре на изазове пандемије COVID-19 која је погодила сеоска домаћинства. Студија полази од идеја афроцентризма како би проценила реакцију вођа локалне заједнице на пандемију током првих 65 дана закључавања Јужноафричке Републике због вируса COVID-19. Подаци су сакупљени у полуструктурираним интервјуима како са локалним сеоским вођама, тако и са локалним општинским тимом задуженим за мере током пандемије COVID-19. Утврђено је да не би био постигнут никакав значајан напредак да локално руководство није прилагодило националну стратегију за борбу против вируса COVID-19 конкретној ситуацији у заједници. Стога студија препоручује свеобухватно укључивање свих заинтересованих страна и приступ од дна ка врху приликом израде стратегија за спречавање пандемије како би стратегија могла да одговори на променљиву динамику у различитим регионима ове земље.

Кључне речи: афроцентризам, пандемија COVID-19, национално закључавање, друштвено-економски изазови, сеоска домаћинства

\footnotetext{
1 kingsley101amaechi@gmail.com

2 Ishmael.iwara@gmail.com
} 
Кинсли Е. Амаечи, Ишмаел О. Ивара, Фаит Мусвипва, Рејмонд Раселекоане, Процена...

\section{Увод}

Пандемија коронавируса (COVID-19) која је избила крајем 2019. године покренула је до тада незабележену реакцију земаља широм света (Kumari \& Toshniwal, 2020; Iwara; Amaechi, Musvipa \& Raselekaone, 2020). У већини случајева, ове реакције су подразумевале спровођење веома строгог затварања економских и друштвених активности у циљу спречавања даљег ширења вируса. То се односи на мере попут ограничења путовања, забране јавних и друштвених окупљања (укључујући и верску службу), затварање фирми и тако даље (Iwara et al., 2020). Извештаји Светске здравствене организације показују да не постоји ниједна земља у свету која није усвојила бар један облик ових ограничења у одговору на пандемију, што је крајње прихватљиво.

У Јужноафричкој Републици, овај одговор је углавном поштовао строг приступ друштвено-економског закључавања у складу са захтевима СЗО. Одговор владе је, између осталог, укључио и петостепене нивое упозорења у погледу економских и друштвених ограничења и карантина (при чему пети степен представља највиши ниво ограничења). Пети степен у трајању од 35 дана (од 26. марта до 30. априла) односно четврти степен у трајању од 30 дана (од 1. до 31. маја), захтевали су затварање граница, забрану путовања између провинција осим повратка на посао уз доказ о запослењу и у изузетним случајевима као што су сахране (уз одобрење), као и забрану друштвених и економских активности, осим за запослене у здравству (South African Government, 2020). Ипак, захваљујући бољој епидемиолошкој ситуацији и стопама опоравка, као и озбиљним негативним дејствима пандемије на привреду (Arndt et al., 2020), земља је прешла на трећи степен који подразумева блажа друштвена и економска ограничења (Republic of South Africa, 2020). До децембра 2020. важио је карантин другог степена, када је откривена нова варијанта вируса која се много брже ширила. Поново је уведен донекле прилагођен трећи ниво карантина (South African Government, 2020).

Мере контроле које је увела влада Јужноафричке Републике очигледно су имале значајну улогу у управљању и смањењу брзине којом се ширио вирус. Међутим, оне су донеле озбиљне друштвено-економске изазове домаћинствима у земљи (Arndt et al., 2020), поготово онима у сеоским заједницама (Iwara et. al., 2020). Имајући у виду чињеницу да бројна домаћинства у тим областима у огромној мери зависе од малих неформалних фирми и пољопривреде (Fransman \& Yu, 2019; Mukumbang et al., 2020), постало им је изузетно тешко да се баве својим делатностима током карантина (Iwara et al., 2020).

Занимљиво је то што строге мере контроле нису једини разлог због којег људи у сеоским домаћинствима сматрају да је живот током пандемије пун изазова; и деловање локалних вођа такође има улогу у томе (Dirani et al., 2020; Ghosh, 2020; Haffajee \& Mello, 2020). Начин на који локалне вође у разним заједницама тумаче национално закључавање утицало је на живот појединаца у локалним заједницама, на њихов доживљај и схватање пандемије. Иако живот током пандемије ублажен је захваљујући удруженом деловању чланова заједнице и мера које су увеле локалне вође у одговору на конкретне изазове са којима су се суочили појединци у оквиру заједнице (Dirani et al., 2020; Ghosh, 2020; Haffajee \& Mello, 2020). Начин на који се посматрају посебне 
потребе и изазови унутар заједница утиче на то како ће пандемија бити протумачена и доживљена у о тим заједницама (Semi-annual Report of the Latin America and Caribbean Region, 2020). Упркос томе, ова значајна анализа је недовољно истражена у ранијој литератури Јужноафричке Републике о вирусу COVID-19. Ова студија представља покушај да се надокнади овај недостатак.

Анализа улоге коју локалне вође имају у тумачењу пандемије и искуствима домаћинстава у сеоским областима полази од документације и проучавања интервентних стратегија које примењују вође села Тсвинга у погледу друштвено-економских изазова током петог и четвртог степена упозорења (првих 65 дана карантина због пандемије COVID-19 у Јужноафричкој Републици). Локалне вође из овог села су, у складу са локалним општинским извештајем о пандемији COVID-19 (Thulamela COVID-19 Report, 2020) међу првима показали одличан пример како треба пронаћи стратегије које ће помоћи лакшем реаговању на неке друштвено-економске изазове пред сеоским домаћинствима, о чему говоре Iwara et al., 2020. Због тога се ова студија руководи према следећим питањима: (а) Које стратегије су локалне вође у селу примениле у односу на изазове? (б) које је образложење за ове стратегије? и (в) на које начине су стратегије помогле у одговору на јединствене изазове са којима су се сеоска домаћинства суочавала током периода од 65 дана?

Наша дискусија заснована је на афроцентристичкој литератури, чији је, пре свих, представник Молефи Кете Асанте (Molefi Kete Asante, 2010), чији филозофски и концептуални оквир афроцентризма отелотворује конструктивно прилагођавање афричкој оријентацији, усредсређености и вери у афричке вредности као доносиоца решења за локалне проблеме унутар афричког континента. Аргумент је да се решења за локалне проблеме у Африци лакше добијају у локалној афричкој заједници, од људи код којих постоји тај проблем. Имајући у виду истоветност култура и заједничке системе вредности, актери у оквиру заједнице имају једни друге и сматра се да су у бољој позицији да схвате и понуде решења за проблеме у одређеним заједницама (Asante, 2010). Исто тако, они су у бољој позицији да схвате како конкретне мере (чак и ако се преузму из другог окружења) могу правилно да се примене у циљу проналажења правог решења за изазове у оквиру њихових сопствених заједница (Asante, 2010).

Не би требало погрешно схватити да су решења заснована на евроцентристичком, епистемолошком и филозофском погледу у основи неадекватна. Уместо тога, наша поента јесте да решења за локалне проблеме треба тражити од локалног становништва. Другим речима, она би требало да буду заснована и усвојена на локалном нивоу. Чак и када су проблеми наметнути са стране, они и даље изискују локално тумачење. Додуше, пандемија COVID-19 је глобални проблем, али се њени утицаји на разне афричке заједнице односе искључиво на те заједнице. Стога би јединствена решења донета у тим заједницама најпогоднији начин за бављење изазовима које је пандемија донела заједницама у Африци.

Студија је организована тако да овај увод пружа основне податке и брз преглед постојеће литературе о утицају националног закључавања на сеоска домаћинства у Јужноафричкој Републици. Следи дискусија о методолошким питањима у основи студије. Затим су представљени подаци о кључним стратегијама које вође локалне заједнице примењују у борби са друштвено-економским изазовима, као и са импликацијама 
Кинсли Е. Амаечи, Ишмаел О. Ивара, Фаит Мусвипва, Рејмонд Раселекоане, Процена...

националног закључавања. На крају рада наведене су истакнуте препоруке политике за Јужноафричку Републику, нарочито начин на који она третира сеоске заједнице.

\section{Метод и подаци}

У документовању и процени реакције вођа села Тсвинга, у студији смо применили квалитативни истраживачки план, помоћу којег је могуће забележити различите активности локалних представника одабраног села. За сакупљање података одабране су три групе учесника. То су два члана одбора општине Туламела задуженог за COVID-19, два одборника која представљају село Тсвинга у оквиру општине, и два члана традиционалног сеоског већа из Тсвинге. Детаљне информације о активностима и напорима локалних представника села пажљиво су прикупљане од учесника путем фокус група и полуструктурираних дубинских интервјуа.

Тематска аналитичка техника примењена је за организовање и проучавање података. Ова техника била је идеална с обзиром на то да омогућава пажљиво рашчлањивање реакција локалне владе (као тема) на препознате друштвено-економске изазове са којима су се борила сеоска домаћинства током националног карантина. Метод тематске анализе такође је помогао у процени да ли су се ови напори суштински односили на конкретне изазове пред којима су се нашла домаћинства у селу Тсвинга.

Квалитативни подаци су транскрибовани и категоризовани. Наводи који се односе на реакције владе на разна друштвено-економска питања су пажљиво рашчлањени и кодирани, заједно са различитим групама учесника у оквиру ове студије. За кодирање учесника у документу употребљене су скраћенице TMCT за COVID-19 тим општине Туламела, WC за градске одборнике и TTC за представнике традиционалног сеоског већа Тсвинге. Ове шифре су приказане и у Табеди 1 ради јасног разумевања резултата.

\section{Интервентне стратегије које примењују вође локалне заједнице у одговору на друштвено-економске изазове пред сеоским домаћинствима у Тсвинги}

Из изјава учесника током интервјуа, закључено је да постоји седам тема у интервентним стратегијама које вође локалне заједнице примењују у борби са неколико изазова пред члановима сеоских домаћинстава у Тсвинги током првих 35 дана националног закључавања. То су: 1) снабдевање водом, 2) снабдевање храном, 3) олакшавање приступа здравственим услугама, 4) обезбеђивање додатних прихода за издржавање, 5) пружање информација и психолошке подршке у борби против анксиозности изазване пандемијом COVID-19, 6) Друштвена подршка жртвама породичног насиља и 7) брза реакција и интервенција у вези са криминалним радњама. Ове теме приказане су у Табеди 1 и разрађене у одељку који следи: 


\section{1 Снабдевање водом}

Као што је наведено у Табеди_ првобитна одговорност за снабдевање заједнице Тсвинга водом била је резервисана за локалну општину Туламела. По мишљењу представника општинског COVID-19 тима, ова општина је искористила своја овлашћења гарантована у државној декларацији о пандемији под називом „Ванредно стање у држави”. Проглашавањем „ванредног стања у држави”, општине у многим деловима земље добиле су овлашћење да људима обезбеде додатне залихе воде, хране и осталих основних намирница (у складу са Законом о националном управљању ванредним ситуацијама). Овом декларацијом општине су добиле овлашћење и за нова наменска средства током тих периода пандемије COVID-19. Општина Туламела је, преко новооснованог COVID-19 одбора, могла да мобилише ресурсе за дистрибуцију воде у разна села у оквиру општине.

Приликом дистрибуције воде, локална општина користила је бурад и цистерне. Међутим, дистрибуција воде није обухватила сва домаћинства у селу. Општински напори нису били довољни за решавање кризе са водом у сеоским домаћинствима током 35 дана националног карантина. Ево како један од градских одборника то описује:

„Иако је оитииина обезбеђивала воgу у иистиернама, нису йокривена сва местиа у селу. И gале имамо кризу са водом у мноіим деловима села. Разлої за ово јесие шийо само мали број домаћинситава има йристиуй воgи коју обезбеђује оититиина, Заирраво, оg ове иницијатииве је имао користии само мали број мешитана. Чак и тии малобројни йривилеі̄овани који су имали користии нису стиално добијали воgу... Можемо са сиїурношћу gа кажемо gа је у селу йокривено свеїа неколико делова, gо је оіромна већина мештиана остиавлена gа се бори сама. То је било иижжно." (WC1)

Детаљније објашњење дао је други одборник тврдећи да има више информација о деловању општинског COVID-19 одбора. Овај учесник је признао да су мештани заиста патили оно што он назива „вишеструким недостатком приступа води” током првих 35 дана националног карантина. Упркос томе, он није био спреман да због тога окриви општину. По његовом мишљењу, криза с водом у селу постојала је и пре пандемије COVID-19. То није нешто што би општина успела да реши током периода карантина дугог 35 дана. Ово је његово објашњење:

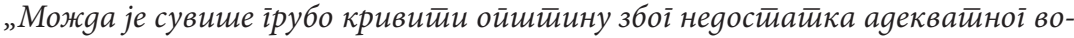
gоснабgевана у селу јер криза са водом је у извесној мери йосйојала и йре йандемије COVID-19. На основу нашеі искустива, йризнајем gа свеїа неколико делова села има gобар gовоg воле јер славине нису функиионисале нити саgа функционишу. Без бу-

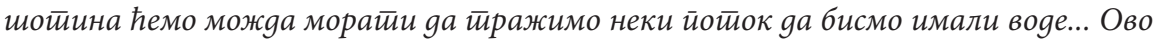
је ояувек био оіроман изазов за наше тьуде. Сийуаиија се gоgайно йоіоршала йоком зактучавань збоі йандемије COVID-19 јер су љуgи били ирриморани gа остиану коg куће. Оишитина није моїла gа реши ирроблем с воgом у йако крайком временском üepuogy." (WC1)

Овај учесник такође је изнео тврдњу да су поједина домаћинства такође несразмерно изостављена због буџетских ограничења општине. И поред тога што је 
Кинсли Е. Амаечи, Ишмаел О. Ивара, Фаит Мусвипва, Рејмонд Раселекоане, Процена...

потреба за пружањем услуга као што је водоснабдевање током пандемије првенствено била заснована на Закону о управљању ванредним ситуацијама који је усвојила влада Јужноафричке Републике, износ средстава обезбеђених за ове услуге и даље је био ограничен, како тврди овај одборник. Одбор је и даље морао да успостави равнотежу између испоруке воде са осталим услугама током датог периода. Због оваквог балансирања општина је била онемогућена да обезбеди неопходне залихе воде домаћинствима којима је била најпотребнија током пандемије.

Наиме, напори општине да свима обезбеди воду нису били довољни за решавање кризе са водом у селу, па су локални представници морали да прискоче у помоћ сеоском становништву. У сарадњи са канцеларијом традиционалног већа, они су успели да обезбеде додатне залихе воде. С обзиром на то да имају приступ подацима ${ }^{3}$ о становницима села, могли су да се усмере на најосетљивије и најсиромашније мештане. Обезбедили су додатну воду старим и болесним лицима, као и трудницама и дојиљама, без обзира на локацију њихових кућа у селу. Испорука воде овде није била ограничена на обичну воду за послове у домаћинству, већ и посебно упаковану воду за пиће, што се сматра веома значајним током овог периода. Ево шта је рекао један од представника традиционалног сеоског већа Тсвинге објашњавајући деловање већа и због чега је оно било важно током датог периода:

„Сйановницима села смо свим срием исйоручивали воgу. Носили смо воgу најсиромашнијим домаћинсиивима у овом селу. Покушали смо gа воgимо рачуна о йоме gа нијеgна сиромашна кућа не буgе занемарена. ...Нисмо се моїл ослонити само на

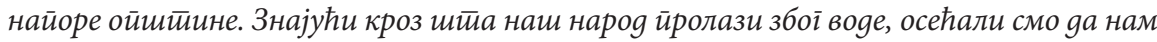

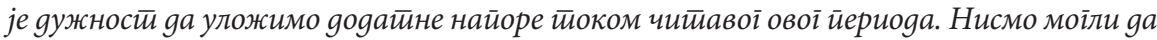

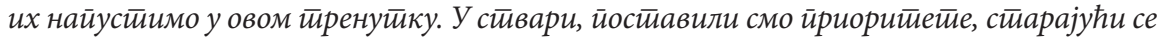
gа имају воgу за gомаће йотиребе. Ово можgа није решило кризу са водом у селу, али сам

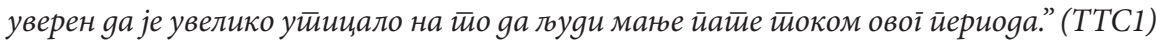

\section{2 Снабдевање храном}

Као и код снабдевања водом, почетни напори у погледу обезбеђивања хране били су такође резервисани за општину. Она је прво убрзано издавала локалним продавницама (spaza) и продавцима на велико дозволе за рад током карантина. Ово се обављало преко COVID-19 тима општине Туламела. Упркос строгим ограничењима слободног кретања људи, овај тим је издавао и дозволе које су појединцима омогућавале да изађу из куће и обаве основне дужности за себе и за чланове њихових домаћинстава. Образложење је било двоструко: 1) да се ипак омогући опстанак малобројним локалним фирмама у оквиру локалних заједница, како би власници могли да издржавају своје породице, и 2) да се води рачуна о томе да, у селима где су мале радње могле да функционишу, локално становништво има лак приступ намирницама током овог периода. Овако је члан COVID-19 тима из Туламеле укратко описао ситуацију:

3 Ови подаци преузети су из локалне базе претходно организоване за дистрибуцију локалних пакета помоћи у селу. 
„Даваюе gозвола за раg локалним малим раgюама обавтьено је йако gа су локалне фирме моіле gа набаве залихе на основу иривремене gозволе gа тудима у својој

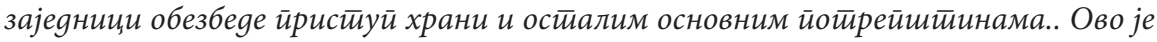
gобар начин за сманене ілаgи у нашим токалним заједницама." (ТМСТ1)

С обзиром на строгу примену правила закључавања, нарочито у погледу ограниченог кретања, ове мере биле су веома значајне. На тај начин је „људима омогућен приступ храни током периода од 35 дана" (TMCT2). Издајући трговачке дозволе локалним малим радњама, сеоско становништво које је имало новца могло је да набави храну не одлазећи у градове.

Још једна важна иницијатива општине у вези са снабдевањем храном била је да се становницима села обезбеде прехрамбени пакети. Нажалост, општина то није могла да оствари током првих 35 дана због буџетских ограничења. Према изјавама учесника, општина је успела да обезбеди прехрамбене пакете само током опасности четвртог степена ${ }^{4}$ јер је на располагању било више средстава (TMCT1). Међутим, замисао о обезбеђивању прехрамбених пакета није занемарена. Њу су прихватили локални представници, пре свих традиционално веће. Традиционално руководство Тсвинге је овде имало значајну улогу. Преко те канцеларије, чланови већа успели су да стекну поверење испоручујући храну сиромашним становницима села. Поверење у традиционално веће олакшало је људима да прихвате храну која им се испоручивала током карантина:

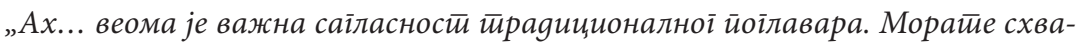

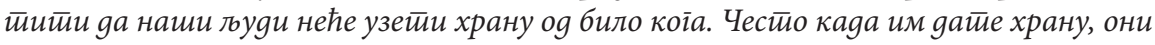
желе gа буgу сиїрни gа је реч о ирравом йоклону, тие gа нема никаквих скривених

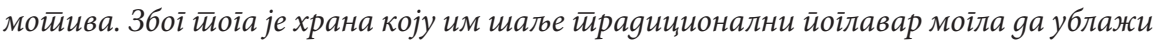
ову врстич стираха." (TTC1)

Захваљујући сагласности поглавара, традиционално веће такође је успело да се повеже са разним заинтересованим странама како би обезбедило донације хране и остале помоћи сиромашнима унутар заједнице. Ово је било у складу са напорима које је улагала општина; премошћавање јаза између појединих сеоских домаћинстава којима су били преко потребни прехрамбени пакети, као и оним домаћинствима која су могла сама да приуште храну из локалних малих радњи. С обзиром на то да традиционално веће одлично познаје заједницу, испорука хране одвијала се сасвим неометано. Ево како је представник традиционалног већа објаснио како су деловали и како је њихово добро познавање сеоских прилика помогло у неометаној испоруци хране:

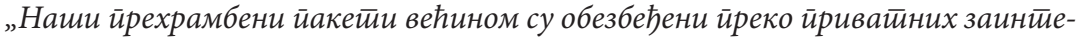

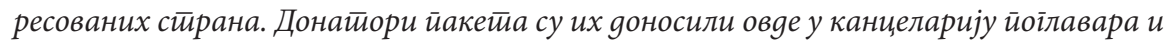
тьgа су gолазили gа их йреузму, ӣо ірруйама. Расйоgела се обавтьала на нивоу већа и

4 Током овог периода, општина Туламела је успела да испоручи пакете хране малом броју сиромашних и незапослених људи у оквиру општине, а на основу општинске базе података. Они су се повезали са Одељењем за друштвени развој (ТМСТ 2). Ипак, напори општине у овом периоду нису били довољни. Стога су општини помогла традиционална већа и остали локални представници у оквиру села. 
Кинсли Е. Амаечи, Ишмаел О. Ивара, Фаит Мусвипва, Рејмонд Раселекоане, Процена...

на нивоу кућних савет̄а. Кућни саветии би означили сиромашне йородице у зајеgници јер они раgе gирекиино са локалним сииановнишитвом у разним деловима іраяа. Они су йакође користиили ситисак из базе йоgатиака како би уйврgили ко има ирраво на иррехрамбене йакетие. Имајйе на уму gа је овај сиисак найрављен мноіо йре йандемије COVID-19 затио шито смо и раније имали сиромашне љуgе у селу. Приметујући овај метиоg, йоgела хране се о ввијала без сметиюи. Моіуу да кажем нисмо добили іойово нијеgну иримеgбу. Можете еи тио замислитич?” (ТТС1)

\section{3 Олакшавање приступа здравственим услугама}

Активности локалних вођа у Тсвинги такође су биле веома корисне када је реч о здравственим питањима. Учесници су потврдили да су се локалне вође повезале са припадницима полиције како би осигурали да не буде ограничења за кретање људи, нарочито оних којима је потребна медицинска помоћ у оквиру села. Ево како је то објаснио представник традиционалног већа:

„Сасвим добро смо се ухватиили у коштиаи, са здравстивеним изазовима унашем селу. Знали смо колико је важно зgравље. Овgе не можете gа се иірайе с тиим стиварима, нарочитио каяа смо свесни gа йојеgинци имају хроничне болесиии као

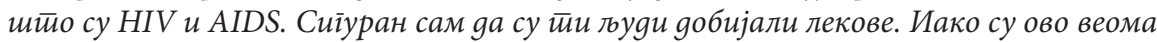

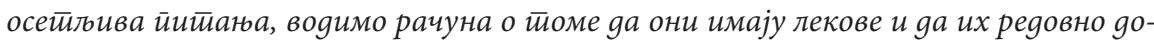
бијају... Чланови наше зајеgнице, йоі̄ойово они са хроничним болестичма, добијали су лекове у локалној клиници.” (ТТС 1)

Један од градских одборника изразио је слично мишљење:

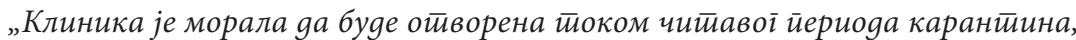
ирре свеїа gа би изашла у сусрети тудима са разним хроничним болестиима... Такође смо имали среће gа се у нашој зајеуниии клиника налази на месииу їgе свако може gа gође у сваком йренуйку. Љуgи су моіли блаіовремено gа оgу ӣо лекове и није било оіраничень кретиана каяа је реч о здравстивеним иичйанима." (WC1)

Све ове ставове је заправо поткрепио и вођа COVID-19 тима из Туламеле. Вођа тима је одмах објаснио да је његова канцеларија уложила додатне напоре како би људима обезбедила приступ здравственим услугама. Према његовом, издавали су дозволе за кретање како би људи у сваком тренутку могли да посете болнице и клинике.

Ово не би требало протумачити као кршење националних прописа Јужноафричке Републике о пандемији COVID-19. Издајући дозволе за одлазак до здравствених институција, и општински COVID-19 тим и традиционално веће су такође покушали да охрабре људе да поштују националне прописе о пандемији, које су подразумевале правилну хигијену, стално прање руку и ношење маске. Наиме, канцеларија традиционалног поглавара је све време бесплатно делила маске.

„Неки тьуи су донирали маске. Неко је gао донацију оg 300 маски. Оне су йоgельене туяима из канцеларије йраяиционалної ӣоілавара. Добијали су маске ӣре неі̄о шито оgу gа ирреузму социјалну йомоћ како се не би излаїали ойасностии оg заразе." (TTC1) 


\section{4 Обезбеђивање додатних прихода за издржавање}

У анализи изјава учесника види се да су сви они уверени у значајну улогу владе у борби са изазовима у погледу ограничених ресурса услед економског закључавања и мера штедње током националног карантина. Учесници су потврдили и похвалили напоре владе да повећа постојећу социјалну помоћ и да свим незапосленима у земљи исплати додатни износ од 350,00 ранда. Напори локаних вођа у том погледу су стога били комплементарни јер су подразумевали попуњавање државних фондова, као и вођење рачуна о томе да људи који имају право на државну помоћ буду упознати са тиме како, где и када да се пријаве за та средства. Следи неколико изјава које потврђују претходно изнет став:

„Влаgа је решила йроблем са неgостиайком ӣрихоgа збої мера шйеgюе и закључаваюа обезбедивши бесйоврайна средстива за социјалну йомоћ. Незайослени стиановници Јужноафричке Рейублике и они који су изіуубили йосао/зайворили фирме gобијали су 350 ранда месечно йреко Јужноафричкої завоgа за социјално осиіуране

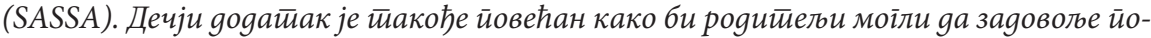
йребе gомаћинсиива. Наша улоїа била је gа льудим йомоінемо gа йровере gа ли имају ирраво на йомоћ и gа знају їgе, каgа и како gа се йријаве gа би добили новаи." (WC2)

„После исйлаие gржавних средстиава, найравили смо и йакозвану банку хране, која је била оg користии у борби са изазовима услеg неgосииаика иррихода. Та храна банке је местио їgе су льуgи из различитихх сектиора и зајеgнииа доносили донације хране за сиромашне стиановнике у окруіуу Вембе. Такође смо ревияирали оититински

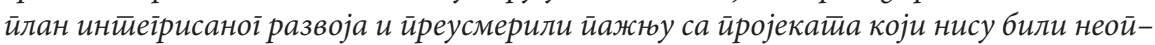

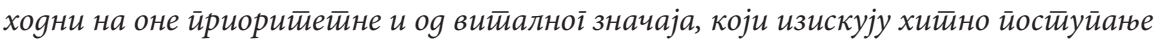
у вези са йандемијом COVID-19." (TMCT1)

„Каgа је реч о ресурсима, имали смо срећу у овом селу јер имамо йројекай еко-йарка који финансирају Трусти за развој Мфафулија и Краљевско веће Тсвиніее. На овом йројекӣу аніановано је 157 мешитана. Постиарали смо се gа зайослени gо-

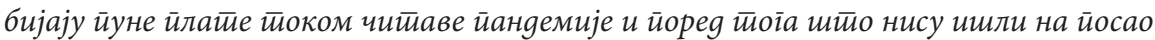

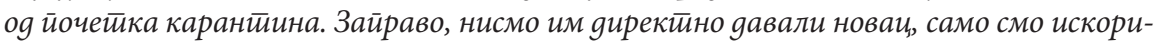

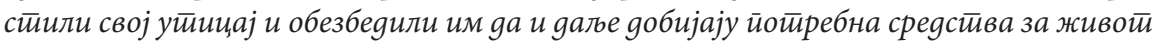
йоком ової йериоgа." (ТTC1)

Ови напори били су изузетно корисни, нарочито када је реч о додатној помоћи приликом пријаве за средства. Тако је мештанима села, пре свега онима који не знају да пишу, био обезбеђен приступ понуђеним државним средствима током овог периода. Захваљујући овој врсти подршке, опстанак током карантина био је олакшан већини људи.

\section{5 Пружање информација и психолошке подршке} у борби против анксиозности изазване пандемијом COVID-19

Ослањајући се на дугогодишње искуство у раду са мештанима села, руководство локалне заједнице је веома рано увидело да ће међу највећим изазовима пред људима у заједници могли бити недостатак знања и неопходних информација о 
Кинсли Е. Амаечи, Ишмаел О. Ивара, Фаит Мусвипва, Рејмонд Раселекоане, Процена...

вирусу COVID-19. Многи нису разумели природу вируса, начин његовог ширења и заразе, нити његов утицај на имунолошки систем. Овакав недостатак знања могао је да проузрокује много стрепње и нелагодности у селу (Iwara et al., 2020). Такође jе могао да доведе до незадовољства и депресије јер људи заправо нису знали шта да раде. У том смислу је оцењено да је неопходан висок ниво свести и сензитизације. У наставку је објашњење једног од градских одборника о томе шта су они предузели.

„Пуйем меgија смо ширили информације о вирусу COVID-19. У истиу сврху смо

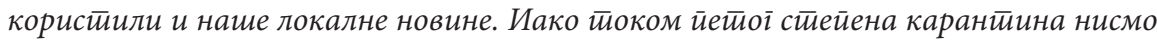

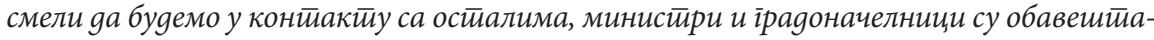
вали јавности у вестимма на тетелевизији и раgију." (WC1)

Поред традиционалних медија, локални градски одборник затим је објаснио како су користили друштвене мреже за ширење порука о вирусу COVID-19. У сарадњи са традиционалним већем, вође локалне заједнице направиле су страницу на друштвеној мрежи Facebook да би село стално добијало информације о коронавирусу. Ово је омогућило правилно обезбеђивање информација многим мештанима. Ево како је овакав приступ описао један од вођа локалне заједнице:

„... Преко наше Facebook стиранице о бборници су моїли gа gеле важне инфор-

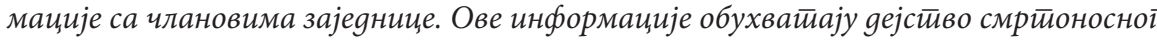
вируса, йроцеgуре ӣријаве и йлаћаға у оквиру Завоgа за социјално осиіуранье (SASSA), gечји gоgайак, йомоћ за стиаре особе и особе са инвалияийейом. Ово нам йакође иомаже gа gобијемо gирекитне информације оg чланова зајеgнице." (WC1)

Међутим, знајући да огромна већина мештана села нема приступ дигиталним уређајима за Facebook, употребљена су и друга средства за ширење информација. Једно од њих био је и сеоски гласник који је преносио јавне објаве на сеоским улицама.

„Користили смо системе јавне комуникације йако шито је ауйомобил ишао улииама и ирреносио информације каg іол је йо било неоиххоно. Појеgине нейрофийне оріанизације су, у сараgюи са Одељенима за социјални развој и здравле, ииакође

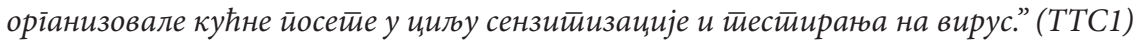

Ове услуге употпуњавао је и COVID-19 тим општине Туламела. Наиме, овај тим такође говори како су се удружили са интерним одељењем за управљање животном средином и отпадом у оквиру општине. Те заинтересоване стране помогле су у изради докумената о здрављу који су коришћени за ширење информација о вирусу COVID-19 у сеоским заједницама унутар општине.

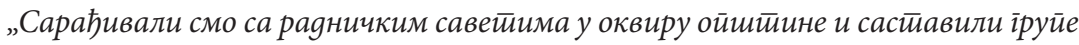

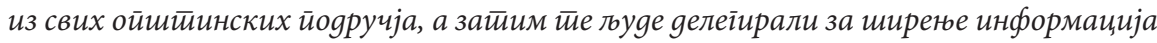
у ниховим заједницама..” (ТМСТ1)

Вође локалне заједнице тврдиле су да ови различити видови ширења информација помажу да се добију преко потребне информације о пандемији COVID-19. На тај начин су се људи смирили и били у стању да се боре са страховима од вируса током читавог овог периода. 


\section{6 Друштвена подршка жртвама породичног насиља}

Вође локалне заједнице такође су допринеле пружању подршке жртвама породичног насиља током датог периода. Према учесницима студије, ова подршка углавном је пружана у виду саветовања и пријаве случајева насиља локалним полицијским станицама (SAPS). Вође локалне заједнице су у вези са овим питањем навеле следеће:

„Имамо мноїо случајева йородичної насиља, нарочитио од йочейка каранииина.

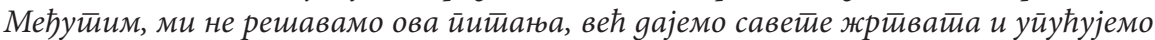
их у йолицију. Такође иррайимо жрииве у нареgном йериоgу. Увек смо на ойрезу и у

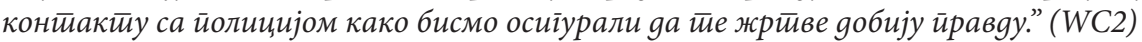

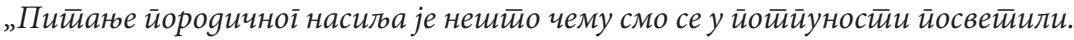
Пре карантиина су ко нас іостиовали стиручғаци из Проірама оснаживаға жрииава Тохојанgоу (TVEP) и обучавали зајеgнииу о йитиатима у вези са йородичним насиљем

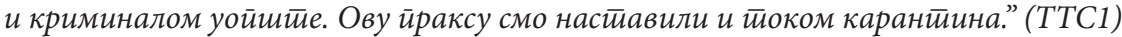

\section{7 Брза реакција и интервенција у вези са криминалним радњама}

Као и у случају породичног насиља, проблеми са криминалом нису обавезно у домену рада локалних представника. Упркос томе, вође локалне заједнице су се укључиле због додатног притиска изазваног ситуацијама у којима су се нашли мештани села током овог периода. Представници традиционалног већа и градски одборници су се током читавог овог периода подједнако трудили да убрзају пријављивање криминала локалним полицијским станицама у Јужноафричкој Републици. По њиховом мишљењу, ово је помогло становницима села да се изборе са изазовима који су проистекли из карантина. Један од градских одборника каже:

„У йрвим gанима карантиина убрзали смо сараgну са локалном йолицијом. Саgа раяимо іотиово као йолицијски службеници. Брзо смо йријавльивали сваки случај

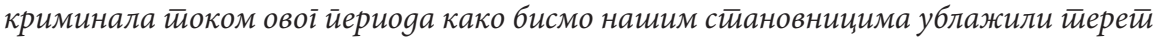
ироузрокован караниичном." (WC2)

Овај став подудара се са мишљењем једног од вођа локалне заједнице. Он је у погледу поменутог проблема изјавио:

„...Иако нисмо решавали случајеве јер тио није наша наgлежносй, ӣрослеgили смо све случајеве криминала йолицији. Сарађивали смо са йолицијом како бисмо

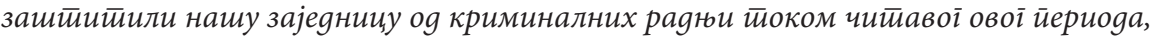
а влаgа нас је йоgржала у йоме." (ТTC1)

Овај вођа локалне заједнице додао је и следеће:

„У сиивари, gа бисмо сирречили йлачке, иирудили смо се gа све време будемо на оирезу и gа йолицији ирријавимо свако сумюиво крейаюе. Полицијске йайроле су иовремено обилазиле све gелове зајеgнице. Они заистиа о олично раgе." (ТTC1)

Boђа COVID-19 тима општине Туламела такође је изнео слично мишљење о општинском приступу током овог периода, а у складу са Законом о управљању ванредним ситуацијама: 
Кинсли Е. Амаечи, Ишмаел О. Ивара, Фаит Мусвипва, Рејмонд Раселекоане, Процена...

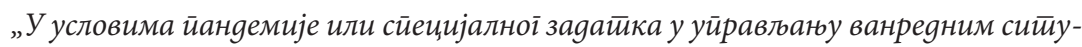
ацијама йостиоји Оgбор за зајеgничко деловане (JОC). Ово је ииело које се састиоји оg различитихх одељена и које је заяужено за уйврђиване зајеgничкоі ӣрисииуйа ӣроблемима криминала и тиако дале и за сараgюу са локалним йолицијским стианицама у Јужноафричкој Рейублици." (ТМСТ1)

\section{Локални одговор на глобалну пандемију?}

Поступање вођа локалне заједнице Тсвинга током првих 35 дана националног закључавања у Јужноафричкој Републици је доказано веома добар пример локалног реаговања на глобалну пандемију. Ово је типичан пример како локални актери могу да обезбеде локална решења са релативно глобалним импликацијама. Седам препознатих стратегија (представљеним по темама) баве се неким од многобројних друштвено-економских изазова који су препознати у претходним студијама (Iwara et al., 2020) као приоритетни за сеоска домаћинства у округу Вембе током националног карантина због пандемије COVID-19. Стратегије су проистекле из основних уверења и вредности које људи у селу Тсвинга повезују са изазовима проистеклим из националног закључавања услед пандемије COVID-19. Иако је држава имала надлежност у складу са Законом о управљању ванредним ситуацијама, примена начела овог документа тумачена је на локалном нивоу. Локално тумачење је максимално повећало сврсисходност закона у налажењу правилног решења за изазове са којима су се суочили људи у овом селу. С обзиром на то да су вође заједнице добро разумеле свој народ, културу и систем вредности, могли су да осмисле посебне стратегије које су биле у складу са стратегијама државне владе у погледу посебних изазова за домаћинства током првих 35 дана карантина.

Друштвено-економски изазови у селу Тсвинга (као што су недостатак основног знања о самом вирусу, недостатак основних објеката и услуга као што су путеви, храна, вода, здравствене установе итд.) очигледно се не разликују драстично од изазова са којима се суочавају остале сеоске заједнице током пандемије COVID-19 pandemic (Arndt et al., 2020; Drummond \& Snowball, 2019; Emenike et al., 2017; Fransman \& Yu, 2019; Iwara et al., 2020; World Bank, 2020, Gabriel \& Robinson, 2020). Ипак, зато што су изазови тумачени на локалном нивоу и зато што су усмерени на заједницу и проистекли из система уверења дате заједнице, различите стратегије које су увеле локалне вође имале су јединствену путању. Ово се односи, на пример, на: додатно препознавање сиромашних и старих лица којима су храна и вода били најпотребнији путем постојеће сеоске базе података; олакшавање приступа здравственим услугама; благовремено и убрзано извештавање и праћење криминалних активности; пружање емоционалне подршке и помоћи жртвама породичног насиља; ширење информација о вирусу путем друштвене мреже Facebook, дељење памфлета и информације које објављује градски гласник; и, напослетку, пружање помоћи мање образованим људима у селу о томе како да се пријаве за додатну државну помоћ. Све ово су наизглед мање значајне, али јединствене стратегије које се највероватније нису примењивале у осталим заједницама. Те јединствене стратегије су биле посебно усмерене на конкретне изазове ас којима су се становници села суочили током првих 35 дана карантина 
(нпр. несташица хране и воде; повећан број случајева породичног насиља и осталих криминалних активности; криза са хроничним болестима; недостатак информација о вирусу COVID-19 и, самим тим, анксиозност коју то проузрокује; релативни недостатак образовања код старијих становника села). Пошто су добро познавале своју заједницу, локалне вође у Тсвинги биле су у стању да смисле стратегије које су биле у складу са напорима како општине, тако и националне владе у одговору на неке од изазова пред којима су се нашла домаћинства у селу. Очигледно је да такво реаговање на изазове људима у селу донекле олакшава борбу са тим изазовима.

Посебно треба издвојити замисао о помагању људима који нису умели да се пријаве за државну помоћ и додатна средства током овог периода. Иако је влада увела мере социјалне помоћи (повећање социјалне помоћи од 500 ранда, као и износ од 350 ранда свим незапосленима у земљи, било је неопходно попунити разне обрасце за пријаву (COVID-19 Corona Virus South African Resource Portal, 2020). Разне студије (Delany \& Jehoma, 2016; Zembe-Mkabile et al., 2015; Wright et al., 2015) показују да у већини случајева људи у сеоским подручјима не умеју да попуњавају обрасце, па им је често тешко да се пријаве за државну помоћ која им је намењена. У тим случајевима државна помоћ губи смисао јер људи не могу да јој приступе. Стога је пружање помоћи у пријављивању за та средства била добро осмишљена и корисна активност која је помогла бројним домаћинствима да попуне обрасце, односно онима који нису знали где да се пријаве. Ово је типичан пример за локално руководство које разуме потребе своје заједнице и које локализује односно тумачи своја овлашћења из Закона о управљању ванредним ситуацијама како би се позабавило конкретним изазовима у оквиру заједнице. Ово се разликује од очигледно честе праксе у многим другим сеоским заједницама у бројним мање развијеним друштвима (Ghosh, 2020; Wilkinson, 2020), где локалне вође често више воле да у потпуности пресликају приступ из директива националне владе. Иако овакви национални приступи имају одређену заслугу, њихово тумачење и примена у заједницама треба да буду „локални”, тј. да се баве конкретним изазовима са којима се суочавају сеоске заједнице. Како тврде Алекс де Вал и Пол Ричардс (Alex de Waal \& Paul Richards, 2020)), управо захваљујући овим локалним тумачењима и иницијативама се долази до погоднијих решења. Уједињени национални приступ је бесмислен уколико се не протумачи у локалној верзији.

Оно што делује као најважнија поука јесте да би локална тумачења и решења требало да буду основа за реаговање на локалне изазове, чак и у ери глобалне пандемије. Ток заразних болести је другачији у различитим заједницама, тј. он зависи од друштвених услова са којима су упознати само локални становници и њихове вође. Основни механизми преношења вируса могу бити исти свуда, али се брзина и образац ширења вируса разликују од места до места (Gupta, Nguyen, Rojas, Raman, Lee, Bento \& Wing, 2020). Густо насељене урбане или полуурбане области имаће другачију путању у односу на локално село као што је Тсвинга. Стога решења за изазове у свакој заједници треба да се локализују и контекстуализују (Asante, 2010).

Не постоје чврсти разлози за занемаривање приступа локалних вођа Тсвинге у одговору на друштвено-економске изазове током првих 35 дана закључавања Јужноафричке Републике због пандемије COVID-19. Начин на који се реаговало на изазове јесте типичан пример како локалне вође правилно схватају локалне изазове и такође усвајају одговарајући приступ тим проблемима. Они су схватили конкретне 
Кинсли Е. Амаечи, Ишмаел О. Ивара, Фаит Мусвипва, Рејмонд Раселекоане, Процена...

изазове са којима се суочавало локално сеоско становништво. Између осталог, у овом селу доминирају домаћинства са ниских приходима и самостална домаћинства чији опстанак зависи од свакодневних привредних и друштвених активности у оквиру оближњих полуурбаних заједница. Ова домаћинства немају додатну уштеђевину „за црне дане”. Тим људима је изузетно тешко да преживе и неколико дана карантина због њихове јединствене друштвено-економске ситуације. Чак и када одговор можда неће адекватно решити све друштвено-економске изазови пред локалним домаћинствима, он сагледава значај локализованих решења за те изазове. Другим речима, неопходно је ангажовање локалних вођа и становника у развоју одговарајућих механизама за решавање локалних изазова чак и када ти изазови имају глобалне последице.

\section{Препоруке}

Имајући у виду значај приступа села Тсвинга, препоручујемо контекстуализацију и локализацију стратегија које се примењују у борби против изазова проузрокованих пандемијом у разним заједницама. Овакав приступ од дна ка врху је пресудан у бављењу неким питањима са променљивим контекстуалним последицама. Он помаже да за сваки одговор на постојеће околности податке директно дају они управо који су директно погођени. Овај приступ такође осигурава да ће мере усвојене на националном плану бити развијене узимајући у обзир околности у којима се нашло локално становништво. Он у суштини служи као начин за повећање моћи локалног и контекстуализованог знања приликом реаговања на кризне ситуације у сеоским заједницама.

Такође препоручујемо социјално мапирање провинција и округа које је више засновано на контексту како би се обезбедило да се мере развијене за спречавање пандемије релевантно односе и примењују на локалне заједнице. Ово је неопходно због тога што различите провинције и окрузи имају сопствену динамику која могуће захтева локализоване стратегије како би мере развијене за спречавање пандемије биле делотворне и како се не би стварали додатни изазови за локалне заједнице.

\section{REFERENCES/ ЛИТЕРATУРА}

Alvesson, M., \& Berg, P. O. (1991). Corporate culture and organizational symbolism: An overview. New York: W. de Gruyter.

Asante, M. K. (2010). Afrocentricity and the argument for civic commitment: Ideology and citizenship in a United States of Africa. The Annals of the American Academy of Political and Social Science, 632(1), 121-131.

Arndt, C., Gabriel, S., \& Robinson, S. (2020). Assessing the toll of COVID-19 lockdown Measures on the South African economy. IFPRI book chapters, 31-32.

Blakely, T., Thompson, J., Carvalho, N., Bablani, L., Wilson, N., \& Stevenson, M. (2020). Maximizing the probability that the 6-week lock-down in Victoria delivers a COVID-19 free Australia. The Medical Journal of Australia, 1. 
Carlitz, R. D., \& Makhura, M. N. (2020). Life under lockdown: Illustrating trade-offs in South Africa's response to COVID-19. World Development, 137, 105168.

COVID-19 Corona Virus South African Resource Portal. (2020b). Sacoronavirus. https:// sacoronavirus.co.za/guidelines-and-relief.

Delany, A., \& Jehoma, S. (2016). Implementation of social grants: Improving delivery and increasing access. Child Gauge, 60. http://www.ceuhealth.uct.ac.za/sites/default/ files/image_tool/images/367/Child_Gauge/2006/Book_Child_Gauge_2016_lowres. pdf\#page $=60$.

Dirani, K. M., Abadi, M., Alizadeh, A., Barhate, B., Garza, R. C., Gunasekara, N., ... \& Majzun, Z. (2020). Leadership competencies and the essential role of human resource development in times of crisis: a response to COVID-19 pandemic. Human Resource Development International, 23(4), 380-394.

Drummond, F. and Snowball, J., 2019. Cultural clusters as a local economic development strategy in rural small-town areas: Sarah Baartman district in South Africa. Bulletin of Geography. Socio-economic Series, 43(43), 107-119.

Emenike, C. P., Tenebe, I. T., Omole, D. O., Ngene, B. U., Oniemayin, B. I., Maxwell, O. and Onoka, B. I. (2017). Accessing safe drinking water in sub-Saharan Africa: Issues and challenges in South-West Nigeria. Sustainable cities and society, 30, 263-272. https:// doi.org/10.1016/j.scs.2017.01.005.

Fransman, T. and Yu, D., (2019). Multidimensional poverty in South Africa in 2001-16. Development Southern Africa, 36(1), pp. 50-79.

Iwara, I. O., Musvipwa, F., Amaechi, K. E., \& Raselekoane, R. (2020). COVID-19 LockDown Socio-Economic Challenges Faced by Households in Rural Areas: A Perspective From Vhembe District, South Africa. Socioloski pregled, 54(3). DOI: 10.59371 socpreg54-27482

Gupta, S., Nguyen, T. D., Rojas, F. L., Raman, S., Lee, B., Bento, A., ... \& Wing, C. (2020). Tracking public and private response to the COVID-19 epidemic: Evidence from state and local government actions (No. w27027). National Bureau of Economic Research.

Haffajee, R. L., \& Mello, M. M. (2020). Thinking globally, acting locally-The US response to COVID-19. New England Journal of Medicine, 382(22), e75.

Hale, T. S. Webster, A. Petherick, T. Phillips, B. Kira (2020). Oxford COVID-19 Government Response Tracker, Blavatnik School of Government Creative Commons Attribution CC BY standard, Data use policy.

Ghosh, J. (2020). A critique of the Indian government's response to the COVID-19 pandemic. Journal of Industrial and Business Economics, 47(3), 519-530.

Kavanagh, M. M., \& Singh, R. (2020). Democracy, Capacity, and Coercion in Pandemic Response - COVID 19 in Comparative Political Perspective. Journal of Health Politics, Policy and Law, 45 (6), 997-1012. https://doi.org/10.1215/03616878-8641530

Kumari, P., \& Toshniwal, D. (2020). Impact of lockdown measures during COVID-19 on air quality - A case study of India. International Journal of Environmental Health Research. DOI: 10.1080/09603123.2020.1778646.

Kumar S \& Sekhar D. C (2020). Response to COVID-19 pandemic in India: How can we strengthen our response? Indian J Community Med 2020; 45(3), 251-255. DOI: 10.4103/ijcm.IJCM_653_20. 
Кинсли Е. Амаечи, Ишмаел О. Ивара, Фаит Мусвипва, Рејмонд Раселекоане, Процена...

Matzopoulos, R., Walls, H., Cook, S., \& London, L. (2020). South Africa's COVID-19 Alcohol Sales Ban: The Potential for Better Policymaking. International Journal of Health Policy and Management. https://dx.doi.org/10.34172/ijhpm.2020.93

Mbunge, E. (2020). Effects of COVID-19 in South African health system and society: An explanatory study. Diabetes \& Metabolic Syndrome: Clinical Research \& Reviews, November-December; 14 (6), 1809-1814. doi: 10.1016/j.dsx.2020.09.016

Mukumbang, F. C., Ambe, A. N., \& Adebiyi, B. O. (2020). Unspoken inequality: how COVID-19 has exacerbated existing vulnerabilities of asylum-seekers, refugees, and undocumented migrants in South Africa. International Journal for Equity in Health, 19(1), 1-7.

Massey, D., \& Jess, P. (1995). A place in the world? Places, cultures and globalization. New York: Oxford Press.

Republic of South Africa Government. (2020a). Regulations issued in terms of Section 27(2) of the Disaster Management Act, 2002. (Government Gazette, 18 March 2020, No 43107). https://www.bpesa.org.za/component/edocman/?task=document.viewDoc\&id=215.

Republic of South Africa (2020b). Statement by President Cyril Ramaphosa on the Progress in the National Effort to Contain the COVID-19 Pandemic. Tuynhuys, Cape Town, $28^{\text {th }}$ December 2020. Sacoronavirus. https://sacoronavirus.co.za/2020/12/28/statement-by-president-cyril-ramaphosa-on-progress-in-the-national-effort-to-containthe-covid-19-pandemic-4/.

Shammi, M., Islam, Bodrud-Doza, M., A., \& Rahman, M. (2020). Strategic assessment of COVID-19 pandemic in Bangladesh: Comparative lockdown scenario analysis, public perception, and management perspectives. Environment, Development and Sustainability, vol. 23, pages 6148-6191. https://doi.org/10.1007/s10668-020-00867-y

South African Government (2020). Regulations and Guidelines - Coronavirus COVID-19. Gov. https://www.gov.za/covid-19/resources/regulations-and-guidelines-coronavirus-covid-19\#.

Thomas, D.F. (2004). Toward an understanding of organization place building in communities. Unpublished doctoral dissertation, Colorado State University, Fort Collins, Colorado.

Thulamela COVID-19 Report, (2020). Unpublished Report by the Thulamela COVID-19 Task Force.

Tuan, Yi-Fu. (1977). Space and place: The perspective of experience. Minneapolis, MN: University of Minnesota Press.

Visagie, J., \& Turok, I. (2020). Rural-urban inequalities amplified by COVID-19: evidence from South Africa. Area Development and Policy, 1-13.

Wilkinson, A. (2020). Local response in health emergencies: key considerations for addressing the COVID-19 pandemic in informal urban settlements. Environment and Urbanization, 0956247820922843.

Wright G., Neves D., Ntshongwana P. \& Noble M. (2015). Social assistance and dignity: South African women's experiences of the Child Support Grant. Development Southern Africa, 2(4), 443-457.

Zembe-Mkabile W., Surrender R., Sanders D., Jackson D. \& Doherty T. (2015). The experience of cash transfers in alleviating childhood poverty in South Africa: Mothers experiences of the Child Support Grant. Global Public Health, 10(7), 834-851. 


\begin{tabular}{|c|c|c|c|c|c|c|c|c|c|c|c|c|c|c|c|}
\hline & 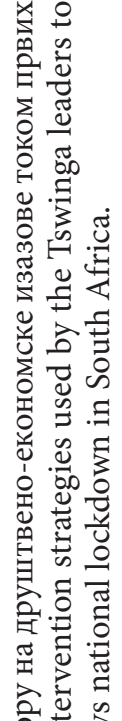 & 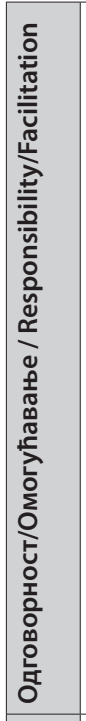 & 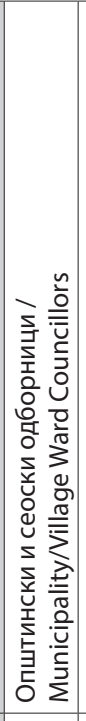 & 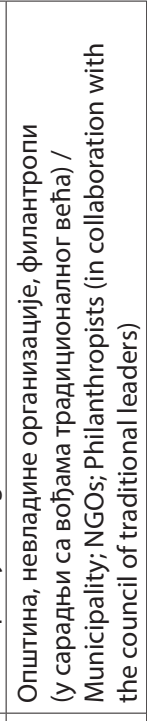 & 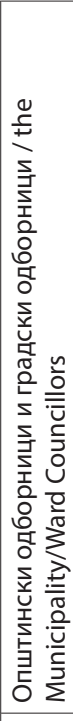 & 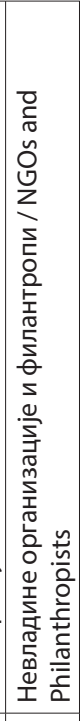 & 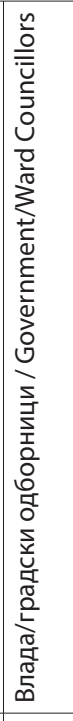 & 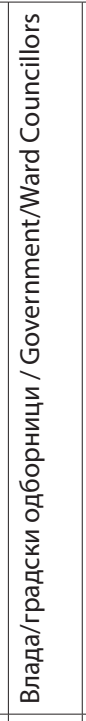 & 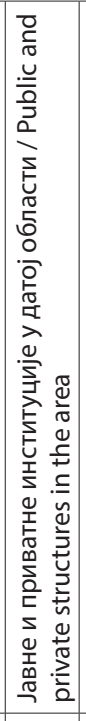 & 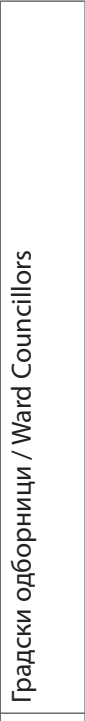 & 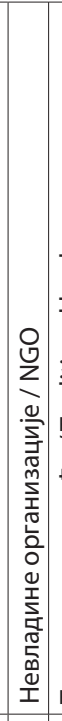 & 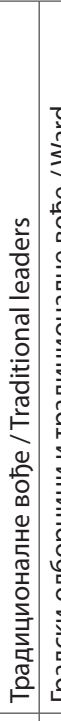 & 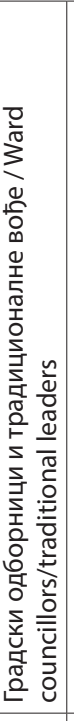 & 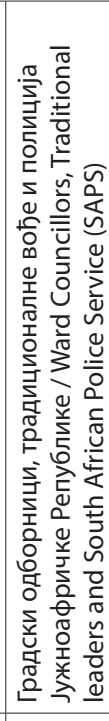 & 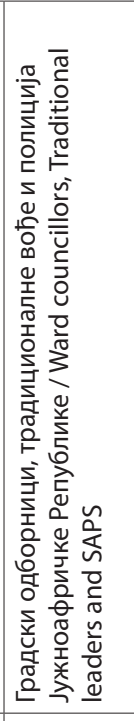 \\
\hline $\begin{array}{l}\text { НАЗАД } \\
\text { ВАСК }\end{array}$ & 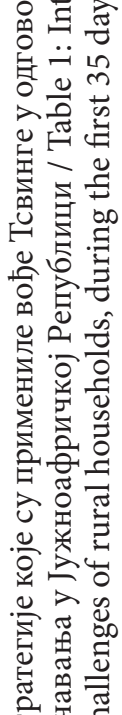 & 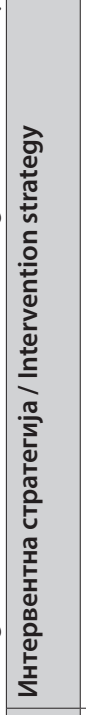 & 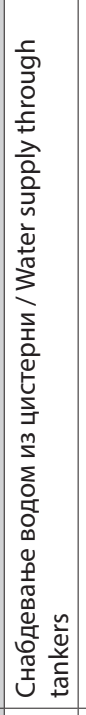 & 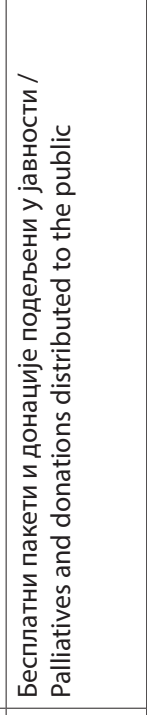 & 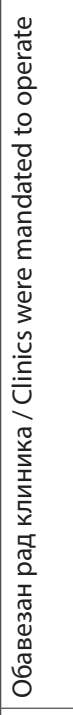 & 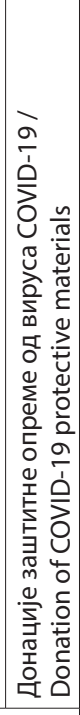 & 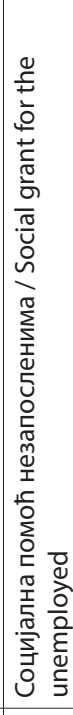 & 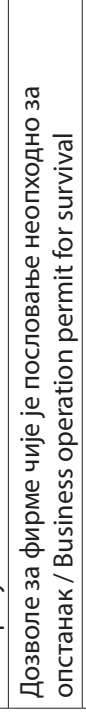 & 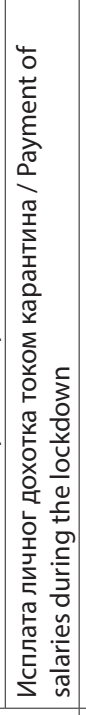 & 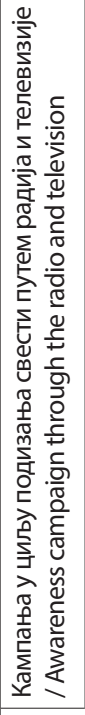 & 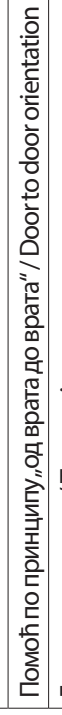 & 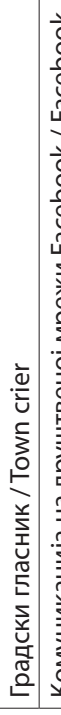 & 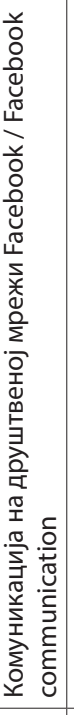 & 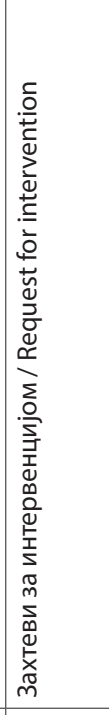 & 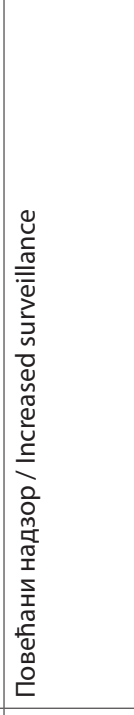 \\
\hline 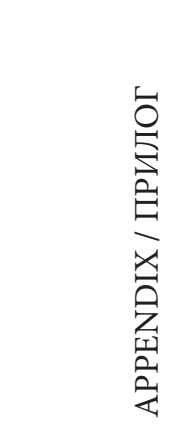 & 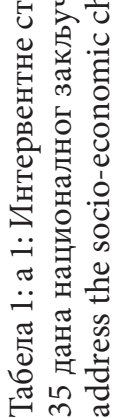 & 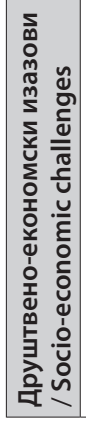 & 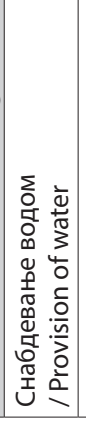 & 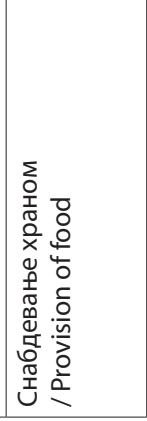 & 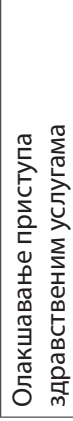 & 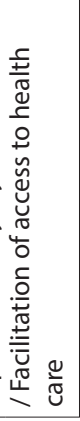 & 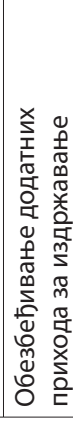 & 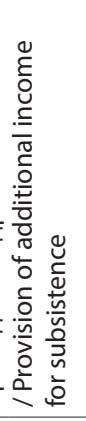 & & 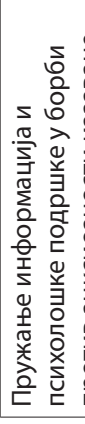 & 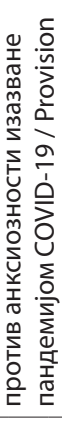 & 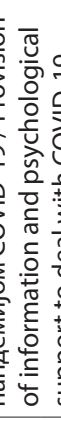 & 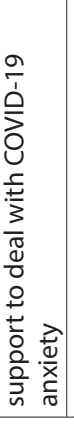 & 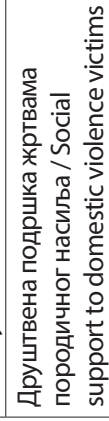 & 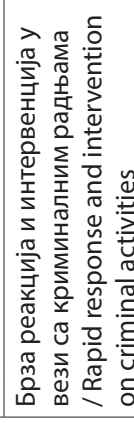 \\
\hline
\end{tabular}

